\title{
Contrasting effects of temperature and winter mixing on the seasonal and inter-annual variability of the carbonate system in the Northeast Atlantic Ocean
}

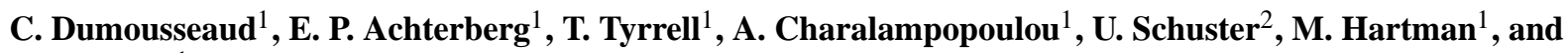 \\ D. J. Hydes ${ }^{1}$ \\ ${ }^{1}$ National Oceanography Centre, University of Southampton, European Way, Southampton, SO14 3ZH, UK \\ ${ }^{2}$ School of Environmental Science, University of East Anglia, Norwich, NR4 7TJ, UK
}

Received: 15 September 2009 - Published in Biogeosciences Discuss.: 8 October 2009

Revised: 3 May 2010 - Accepted: 3 May 2010 - Published: 11 May 2010

\begin{abstract}
Future climate change as a result of increasing atmospheric $\mathrm{CO}_{2}$ concentrations is expected to strongly affect the oceans, with shallower winter mixing and consequent reduction in primary production and oceanic carbon drawdown in low and mid-latitudinal oceanic regions. Here we test this hypothesis by examining the effects of cold and warm winters on the carbonate system in the surface waters of the Northeast Atlantic Ocean for the period between 2005 and 2007. Monthly observations were made between the English Channel and the Bay of Biscay using a ship of opportunity program. During the colder winter of 2005/2006, the maximum depth of the mixed layer reached up to $650 \mathrm{~m}$ in the Bay of Biscay, whilst during the warmer (by $2.6 \pm 0.5^{\circ} \mathrm{C}$ ) winter of 2006/2007 the mixed layer depth reached only $300 \mathrm{~m}$. The inter-annual differences in late winter concentrations of nitrate $\left(2.8 \pm 1.1 \mu \mathrm{moll}^{-1}\right)$ and dissolved inorganic carbon ( $22 \pm 6 \mu \mathrm{mol} \mathrm{kg}{ }^{-1}$ ), with higher concentrations at the end of the colder winter (2005/2006), led to differences in the dissolved oxygen anomaly and the chlorophyll $a$-fluorescence data for the subsequent growing season. In contrast to model predictions, the calculated air-sea $\mathrm{CO}_{2}$ fluxes (ranging from +3.7 to $-4.8 \mathrm{mmol} \mathrm{m}^{-2} \mathrm{~d}^{-1}$ ) showed an increased oceanic $\mathrm{CO}_{2}$ uptake in the Bay of Biscay following the warmer winter of 2006/2007 associated with wind speed and sea surface temperature differences.
\end{abstract}

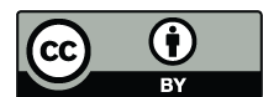

Correspondence to: E. P. Achterberg (eric@noc.soton.ac.uk)

\section{Introduction}

Since the late 1700s, the atmospheric concentration of $\mathrm{CO}_{2}$ has increased from 280 to $380 \mathrm{ppm}$ and the oceans have absorbed about half of the anthropogenic $\mathrm{CO}_{2}$ emitted to the atmosphere (Sabine et al., 2004). While some oceanic regions act as a source of $\mathrm{CO}_{2}$ to the atmosphere, the North Atlantic Ocean is reported as one of the strongest sinks in the world (Takahashi et al., 2009; Takahashi et al., 2002; Gruber et al., 2002). The uptake of atmospheric $\mathrm{CO}_{2}$ by the oceans is however lowering oceanic $\mathrm{pH}$ and the saturation state of calcium carbonate (Orr et al., 2005; Feely et al., 2004; Caldeira and Wickett, 2003). Coccolithophores, coral reefs and other major calcifiers are expected to be affected by future changes in the oceanic carbonate chemistry and pH (Fabry, 2008).

Climate change is predicted to reduce the capacity of the oceans to absorb $\mathrm{CO}_{2}$ through a decrease in winter mixing and a consequent reduced nutrient supply to surface layers and lower primary production during the following spring bloom (Sarmiento et al., 1998; Bopp et al., 2001; Doney et al., 2009). The North Atlantic sink of $\mathrm{CO}_{2}$ has been in decline during the last few decades, related to changes in the North Atlantic Oscillation (NAO), surface circulation, vertical winter mixing, inorganic carbon chemistry, and/or sea surface warming (Schuster et al., 2009; Doney et al., 2009; Schuster and Watson 2007; Corbière et al., 2007; Thomas et al., 2008).

However, the natural small-scale variability of the carbonate system observed in the oceans on a seasonal and interannual basis often makes the prediction of long-term impacts more difficult (Bates et al., 1996a), and highlights the importance of understanding the variability of the carbonate

Published by Copernicus Publications on behalf of the European Geosciences Union. 
system on a regional and global scale. Time-series programs such as the Bermuda Atlantic Time-Series (BATS), the European Station for Time-series in the Ocean, Canary Islands (ESTOC), and the Hawaii Ocean Time-Series (HOTS) have improved our understanding of the processes affecting the carbonate system (e.g. Bates 2007; González-Dávila et al., 2003; Dore et al., 2009). A significant number of other high-resolution observational programs are now operational (Doney et al., 2009), including observations from ships of opportunity as part of the FerryBox program (Hydes et al., 2003) and the CarboOcean project.

The FerryBox route presented in this study covers about $1000 \mathrm{~km}$ from the highly productive and well-mixed waters of the English Channel, to the deep oligotrophic and seasonally stratified waters of the Bay of Biscay (Borges et al., 2006). Due to a complex physical context, the carbonate system and primary production in the English Channel and adjacent areas are subject to large seasonal and spatial variability (Frankignoulle et al., 1996a and b; Wollast and Chou 2001; Bargeron et al., 2006).

The observations made on a ship of opportunity, the $M V$ Pride of Bilbao, constitute a unique dataset of carbonate chemistry measurements in the Northeast Atlantic Ocean surface waters, for two consecutive years. The aim of this work was to observe the natural processes affecting the seasonal and inter-annual variability of the carbonate system and the air-sea $\mathrm{CO}_{2}$ fluxes in the English Channel and the Bay of Biscay. These observations, linked with the changes in winter mixing observed within the two years of our study, will provide a better understanding of how this ocean region may be affected by future climate change.

\section{Methods}

\subsection{Area of study}

The sample collection was undertaken on the ship of opportunity MV Pride of Bilbao, a passenger ferry undertaking weekly crossings between Portsmouth (UK) and Bilbao (Spain). The route covers the area between the Portsmouth harbour and the Iberian shelf (Fig. 1), crossing eight regions of different oceanographic characteristics (Bargeron et al., 2006). However, only the section between the Central English Channel and the Southern Bay of Biscay will be taken into account in this study (zones 2 to 7 in Fig. 1), as no samples were collected in the harbour regions. Thirteen crossings were occupied by researchers between September 2005 and July 2007 (Table 1).

\subsection{Sampling}

All samples were collected from the ship's underway supply (intake at about $5 \mathrm{~m}$ depth). Samples for Dissolved Inorganic Carbon (DIC) and Total Alkalinity (TA) were drawn,

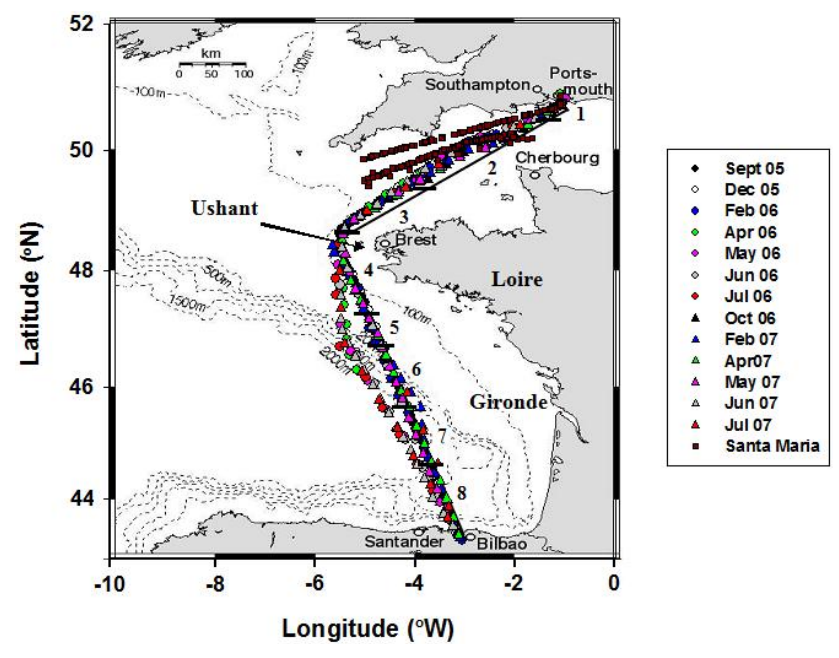

Fig. 1. Location of the FerryBox route and sub-regions associated: (1) Portsmouth Harbour; (2) Central English Channel; (3) Western English Channel; (4) Ushant region; (5) Shelf break; (6) Northern Bay of Biscay; (7) Southern Bay of Biscay; (8) Iberian Shelf. The sampling positions for each crossing are shown as well as the $M V$ Santa Maria track (Figure adapted from Kelly-Gerreyn et al., 2006).

Table 1. Crossing dates (Portsmouth to Bilbao) between 2005 and 2007.

\begin{tabular}{lclc}
\hline Date & $\begin{array}{c}\text { DIC and } \\
\text { TA samples }\end{array}$ & Date & $\begin{array}{c}\text { DIC and } \\
\text { TA samples }\end{array}$ \\
\hline 26 Sep - 29 Sep 05 & 34 (DIC only) & 18 Oct-19 Oct 06 & 39 \\
14 Dec-15 Dec 05 & 33 & 10 Feb-11 Feb 07 & 34 \\
28 Feb-02 Mar 06 & 40 & 04 Apr-05 Apr 07 & 33 \\
10 Apr-11 Apr 06 & 21 & 10 May-11 May 07 & 28 \\
10 May-12 May 06 & 15 & 04 Jun-06 Jun 07 & 32 \\
12 Jun-15 Jun 06 & 27 & 10 Jul-12 Jul 07 & 19 \\
09 Jul-11 Jul 06 & 16 & & \\
\hline
\end{tabular}

unfiltered, in $250 \mathrm{ml}$ borosilicate glass bottles (Schott Duran), with a head space of $1 \%(2.5 \mathrm{ml})$ allowed for water expansion, and immediately poisoned with $50 \mu \mathrm{l}$ saturated solution of mercuric chloride to prevent further biological activity (Dickson et al., 2007). Samples were collected every four hours and stored for later analysis in the laboratory.

Continuous temperature, conductivity and chlorophyll $a$ fluorescence measurements were obtained from a MINIpack system (Chelsea Technologies Group, UK) installed on the ship (Hydes et al., 2003). The salinity data was calibrated using samples taken every two hours on each researcheroccupied crossing, and analysed at the NOCS calibration laboratory using a salinometer (8400 B Autosal, Guildline, Canada). The precision and accuracy of the salinity measurements were \pm 0.1 . Nutrient samples were collected every half hour during the occupied crossings and analysed at NOCS using standard methods on an auto-analyser for silicate, total nitrate (nitrate plus nitrite) and phosphate 
(Grasshoff 1983). The precision and accuracy of the nutrient concentrations were $\pm 0.1 \mu \mathrm{moll}^{-1}$ for nitrate and silicate and $\pm 0.02 \mu \mathrm{moll}^{-1}$ for phosphate. Dissolved oxygen concentrations were obtained using an optode (3930, Aanderaa, Norway) installed on the ship, and calibrated with discrete samples collected every hour and analysed on board by Winkler titration (Hydes et al., 2009). The precision and accuracy of the oxygen measurements were $\pm 1 \mathrm{mmol} \mathrm{m}^{-3}$ (Hydes et al., 2009).

\subsection{DIC and TA measurements}

The analysis of DIC and TA was undertaken using the VINDTA 3C (Marianda, Germany). The DIC samples were analysed using a coulometric titration (coulometer 5011, UIC, USA) and TA was determined using a closed-cell titration according to Dickson et al. (2007). The cell $(100 \mathrm{ml})$ for the TA determination was equipped with a $\mathrm{pH}$ half cell electrode (glass bodied Orion 8101SC, Ross, USA) and an $\mathrm{Ag} / \mathrm{AgCl}$ reference electrode (model 6.0729.100, Metrohm, Switzerland). The calculation of TA was based on a non-linear curve fitting (least-squares) approach (Dickson et al., 2007). All samples were analyzed at $25^{\circ} \mathrm{C}\left( \pm 0.1^{\circ} \mathrm{C}\right)$ with temperature regulation using a water-bath (Julabo F12, Germany). Repeated measurements on the same batch of seawater $(n \geq 3)$ were undertaken every day prior to sample analysis, in order to assess the precision of the method which was estimated for the whole dataset to be $1.1 \pm 0.5 \mu \mathrm{mol} \mathrm{kg}{ }^{-1}$ for DIC and $1.1 \pm 0.6 \mu \mathrm{mol} \mathrm{kg}{ }^{-1}$ for TA. The analytical precision hence was within the previously reported precision range for TA and DIC measurements (Bates et al., 1996a and b; Millero et al., 1998a). Certified Reference Materials (from A.G. Dickson, Scripps Institution of Oceanography) were analysed as standards to calibrate the instrument at the beginning and end of each day of analysis. A daily correction factor was applied to all measured values according to Millero et al. (1998b), in order to standardize the results. To remove the influence of salinity on the distribution of DIC and TA, the data was normalized (nDIC and nTA) to a salinity of 35 (Millero et al., 1998a):

$\mathrm{nDIC}=\mathrm{DIC} \cdot(35 / S)$

$\mathrm{nTA}=\mathrm{TA} \cdot(35 / S)$

Where $S$ is the salinity observed.

The fugacity of $\mathrm{CO}_{2}\left(f \mathrm{CO}_{2}\right)$ measurements available for the English Channel for the period 2006 and 2007 from the ship of opportunity MV Santa Maria (Schuster et al., 2009) were used along with our TA, temperature, salinity and nutrient data to corroborate values of DIC. The in situ $f \mathrm{CO}_{2}$ measured was corrected for the difference between in situ and equilibrator temperature (Schuster et al., 2007). The time and position of measurements in the English Channel by the MV Santa Maria and Pride of Bilbao matched well
(Fig. 1). The calculation was done using the $\mathrm{CO}_{2} \mathrm{SYS}$ program (Pierrot et al., 2006), and the equilibrium constants of $\mathrm{CO}_{2}$ from Mehrbach et al. (1973) refitted by Dickson and Millero (1987) were used for the calculation (Wanninkhof et al., 1999). The uncertainty in the calculation of DIC from TA and $f \mathrm{CO}_{2}$ measurements was estimated to $\pm 3.4 \mu \mathrm{mol} \mathrm{kg}-1$ (Zeebe and Wolf-Gladrow 2001).

The DIC values calculated using the MV Santa Maria $f \mathrm{CO}_{2}$ data and our TA measurements showed good agreement with our DIC measurements (Pride of Bilbao) for the months of December 2005, February 2006, April 2006, October 2006, and July $2007\left(11 \pm 8 \mu \mathrm{mol} \mathrm{kg}{ }^{-1}\right)$. The data for February, April, May and June 2007 showed however large differences between the calculated and the measured DIC values $\left(42 \pm 5 \mu \mathrm{mol} \mathrm{kg}{ }^{-1}\right)$. From these comparisons it became apparent that some of the 2007 DIC data from the Pride of Bilbao required correction. The calculated DIC concentrations for the English Channel were used where direct comparison with the $M V$ Santa Maria data was possible, and a monthly correction factor (calculated from the ratio between the measured and the calculated DIC concentrations) was applied to the February (2.3\%), April (2.1\%), May (2.1\%) and June (1.7\%) 2007 DIC data from the Pride of Bilbao.

\subsection{Coccolithophore abundance}

Up to 21 of seawater was pre-filtered through a $200 \mu \mathrm{m}$ mesh to prevent zooplankton grazing during the filtration. The samples (collected at the same time as the DIC and TA samples) were filtered onto $0.4 \mu \mathrm{m}$ membrane filters of $47 \mathrm{~mm}$ diameter (Isopore, Millipore, USA) using a vacuum of 400$500 \mathrm{~mm} \mathrm{Hg}$ (reduced to $100 \mathrm{~mm} \mathrm{Hg}$ towards the end of the filtration). A glass fibre filter (GF/F, Whatman, UK) was placed underneath the filters to ensure an even distribution of the material on the filter. Filters were rinsed with an ammonium hydroxide solution (approximate $\mathrm{pH} 9$ to 10) to remove seawater salts, left to air-dry and subsequently stored in dark and dry conditions. Before analysis, a small piece of each filter was cut radially, placed on a stub and gold-coated. A Scanning Electron Microscope (Leo 1450VP, Carl Zeiss, Germany) and automated software (SmartSEM, V05.01, Carl Zeiss, Germany) were used to capture and store all images (Tyrrell et al., 2008). The number of coccospheres in each sample was counted on each scanning electron micrograph (SEM) taken (225 per filter, equivalent to an area of $\left.1 \mathrm{~mm}^{2}\right)$ at $5000 \times$ magnification.

\subsection{Air-Sea $\mathrm{CO}_{2}$ flux calculation}

The air-sea $\mathrm{CO}_{2}$ fluxes $\left(\mathrm{F}\right.$, in $\mathrm{mmol} \mathrm{m}^{-2} \mathrm{~d}^{-1}$ ) were calculated as follows (Wanninkhof 1992) for the three day period of each crossing:

$\mathrm{F}=k \alpha \Delta p \mathrm{CO}_{2}$

Where $\Delta p \mathrm{CO}_{2}(\mu \mathrm{atm})$ is the difference between oceanic partial pressure of $\mathrm{CO}_{2}\left(p \mathrm{CO}_{2}\right)$ and atmospheric $p \mathrm{CO}_{2}$ 
(a negative flux would hence correspond to a net transfer of $\mathrm{CO}_{2}$ from the atmosphere to the ocean), $\mathrm{k}$ is the gas transfer velocity $\left(\mathrm{m} \mathrm{s}^{-1}\right)$, and $\alpha$ is the solubility coefficient of $\mathrm{CO}_{2}$ $\left(\mathrm{mol} \mathrm{atm} \mathrm{m}^{-1} \mathrm{~m}^{-3}\right)$. The atmospheric $p \mathrm{CO}_{2}$ data was obtained from the Mace Head (53.33 ${ }^{\circ} \mathrm{N}$; RAMCES/LSCE monitoring network) and the Azores meteorological stations $\left(38.77^{\circ} \mathrm{N}\right.$; NOAA/ESRL Global monitoring division) and averaged for each crossing. The average difference in atmospheric $p \mathrm{CO}_{2}$ observed between the two stations was $1.1 \pm 0.5 \mu$ atm $(r=$ $0.988 ; n=92)$. The oceanic $p \mathrm{CO}_{2}$ data were calculated from the DIC and TA data obtained in this study and averaged for each crossing and each region. The solubility coefficient of $\mathrm{CO}_{2}(\alpha)$ was calculated according to Weiss (1974). The equation of Nightingale et al. (2000), based on an extensive data set of tracer release experiments over a wide range of wind speed measurements (Schuster et al., 2009), was used for the calculation of the gas transfer velocity $(k)$. The equation from Sweeney et al. (2007) was used for comparison and the fluxes calculated following these two equations agreed within $0.05 \pm 0.04 \mathrm{mmol} \mathrm{m}^{-2} \mathrm{~d}^{-1}$. The wind speed data used for the calculation of the gas transfer velocity were obtained from the daily QuikSCAT satellite data (Physical Oceanography DAAC Ocean ESIP Tool (POET) http://poet.jpl.nasa.gov/), monthly averaged for each of the six regions studied. The wind speed data was obtained for $10 \mathrm{~m}$ height on a $0.25^{\circ}$ spatial resolution.

\subsection{External sources of data}

In addition to the chlorophyll $a$-fluorescence data obtained from the MINIpack, the 8-days averaged SeaWIFS chlorophyll- $a$ data (OBPG SeaWIFS 8-day 9-km products http://reason.gsfc.nasa.gov/OPS/Giovanni/ocean.swf8D.

shtml; NASA Ocean Color Time-Series) from the Bay of Biscay and the English Channel for the period between 2005 and 2007 were used to investigate the inter-annual variability.

In order to determine the mixed layer depth (MLD) we used data from four Argo floats located in the Bay of Biscay for the period of our study $(4900557,6900359,6900360$, and 6900362; http://www.coriolis.eu.org/cdc/argo.htm). The MLD was estimated according to the temperature and density criteria which defines the MLD as the shallowest depth corresponding to a temperature or density difference with the surface waters of more than $\Delta \mathrm{T}=0.5^{\circ} \mathrm{C}$ and $\Delta \sigma_{t}=0.125$, respectively (Monterey and Levitus 1997).

\section{Results and discussion}

\subsection{Salinity, temperature and nitrate}

A decrease in salinity and temperature with increasing latitude was observed for each crossing (Fig. 2a and b). The salinity distribution did not show a strong variation throughout the year and ranged for the whole study between 35.2 in the Central English Channel and 35.8 in the Southern Bay of Biscay. Lower salinities of approximately 34.8 were observed in the Ushant region in April 2006 due to freshwater inputs from the French rivers Loire and Gironde (KellyGerreyn et al., 2006). Surface waters in February 2007 were warmer than in February 2006 by $2.6 \pm 0.5^{\circ} \mathrm{C}$ for all regions; whereas July 2007 surface water temperatures were lower than July 2006 by $2.0 \pm 0.7^{\circ} \mathrm{C}$.

Enhanced nitrate concentrations were observed during the winter months, with depleted levels in summer (Fig. 2c). Surface nitrate concentrations were higher during the 2005/2006 winter than during the 2006/2007 winter, whilst summer nitrate concentrations were below $0.05 \mu \mathrm{mol}^{-1}$ for both years and all regions. In the Bay of Biscay, surface nitrate concentrations were higher (up to $8.0 \mu \mathrm{moll}^{-1}$ ) during the winter 2005/2006 than the values reported for the 2003/2004 winter (up to $4.5 \mathrm{mmol}^{-1}$ in February 2004) by Bargeron et al. (2006), whilst in winter 2006/2007 they were comparable (up to $4.1 \mu \mathrm{moll}^{-1}$ ) to those of the 2003/2004 winter (Bargeron et al., 2006). From the English Channel to the Shelf Break, nitrate concentrations in the 2005/2006 winter were similar to the 2003/2004 winter (Bargeron et al., 2006) with an average winter concentration of $7.3 \mu \mathrm{mol} 1^{-1}$, whilst during the 2006/2007 winter they were lower than during the winter 2003/2004 (Bargeron et al., 2006) with an average concentration of $5.4 \mu \mathrm{moll}^{-1}$.

\subsection{Dissolved oxygen anomaly and chlorophyll $a$ -fluorescence}

The dissolved oxygen anomaly at standard pressure $\left(\Delta\left[\mathrm{O}_{2}\right]^{\circ}\right)$ was calculated from the measured dissolved oxygen concentration $\left(\left[\mathrm{O}_{2}\right]_{\text {obs }}\right)$ and the saturation oxygen concentration $\left(\left[\mathrm{O}_{2}\right]_{\text {sat }}^{\circ}\right)$ according to Bargeron et al. (2006); a positive value indicating supersaturation:

$\Delta\left[\mathrm{O}_{2}\right]^{\circ}=\left[\mathrm{O}_{2}\right]_{\text {obs }}-\left[\mathrm{O}_{2}\right]_{\text {sat }}^{\circ}$

The oxygen anomaly distribution (Fig. 2d) showed maxima during periods of high primary production in spring times, and minima during the winter months when oxygen-depleted waters were brought to the surface due to winter mixing (Hydes et al., 2008), resulting in oxygen supersaturated surface waters in spring and undersaturated waters in winter. During spring 2006, dissolved oxygen anomalies were higher than in spring 2007 (up to 53.7 and $39.3 \mathrm{mmol} \mathrm{m}^{-3}$, respectively), whilst during the 2005/2006 winter, they were lower than during the $2006 / 2007$ winter $\left(-2.8\right.$ and $3.9 \mathrm{mmol} \mathrm{m}^{-3}$, respectively). This suggested a shallow winter mixing in $2006 / 2007$, supported by the lower nitrate concentrations (Fig. 2c) observed in the winter of 2006/2007 compared to 2005/2006.

The chlorophyll $a$-fluorescence data (Fig. 2e) provide an indication of the timing of peaks in primary production and of phytoplankton biomass present in the water. The data showed a similar temporal distribution to the oxygen 

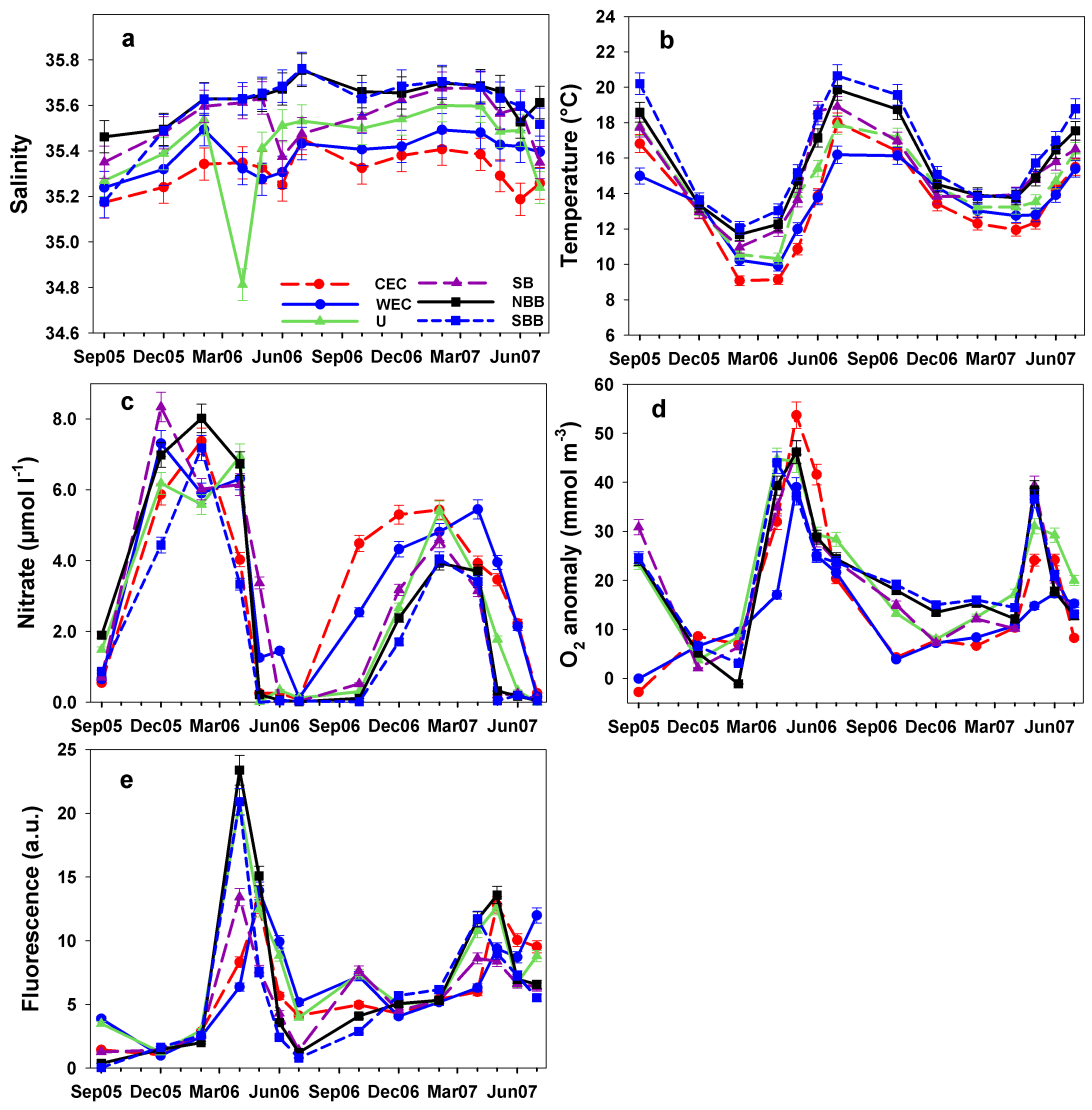

Sep05 Dec05 Mar06 Jun06 Sep06 Dec06 Mar07 Jun07

Fig. 2. Monthly mean of (a) sea surface salinity, (b) sea surface temperature $\left({ }^{\circ} \mathrm{C}\right)$, (c) surface nitrate concentration $\left(\mu \mathrm{mol} 1^{-1}\right)$, (d) dissolved oxygen anomaly $\left(\mathrm{mmol} \mathrm{m}^{-3}\right)$ and (e) chlorophyll $a$-fluorescence (arbitrary units) distribution averaged for each region: Central English Channel (dashed red line; circles); Western English Channel (blue line; circles); Ushant (green line; triangles); Shelf Break (dashed purple line; triangles); Northern Bay of Biscay (black line; squares); Southern Bay of Biscay (short dashed blue line; squares). The error bars represent the standard deviation for each mean. Data points are linearly interpolated between sampling points to allow a clear distinction of observations between regions. It should not be assumed that the interpolation provides an accurate estimate of the missing data.
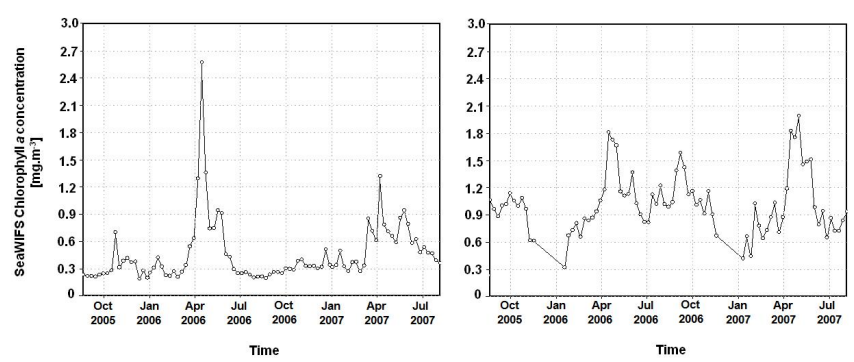

Fig. 3. SeaWIFS chlorophyll- $a$ distribution (8-days average) for the Bay of Biscay area (left) and the English Channel area (right) between September 2005 and July 2007. Graphs generated by NASA's Giovanni (giovanni.gsfc.nasa.gov).

anomaly, with maximum values during spring (23.4 and 13.6 arbitrary units for spring 2006 and 2007, respectively) and minimum values during winter. The spring chlorophyll $a$ fluorescence maximum in the Northern and Southern Bay of Biscay was almost twice as high (1.7 and 1.8 times higher, respectively) in 2006 compared to 2007 (23.4 and 20.9 arbitrary units in 2006 as opposed to 13.6 and 11.7 in 2007 for the two regions), in agreement with the SeaWIFS timeseries chlorophyll- $a$ distributions (Fig. 3). The chlorophyll $a$-fluorescence data for the Shelf Break and Ushant regions also indicated enhanced phytoplankton biomass (1.6 times higher) in 2006 compared to 2007 (20.9 and 13.4 arbitrary units in 2006 as opposed to 12.7 and 8.6 in 2007 for the two regions). The English Channel waters have been described as optically-complex case 2 waters (Vantrepotte et al., 2007; Morel and Prieur 1977) and the interpretation of the optical signal can therefore be difficult and subject to errors. However, the SeaWIFS time-series chlorophyll- $a$ distributions (Fig. 3) appeared to agree well with the temporal trend of the chlorophyll $a$-fluorescence data (Fig. 2e), with little or no inter-annual variability observed in the Central and Western English Channel regions between the two years of our study (12.8 and 13.9 arbitrary units in 2006 and 12.8 and 12.0 in 2007 for the two regions). 

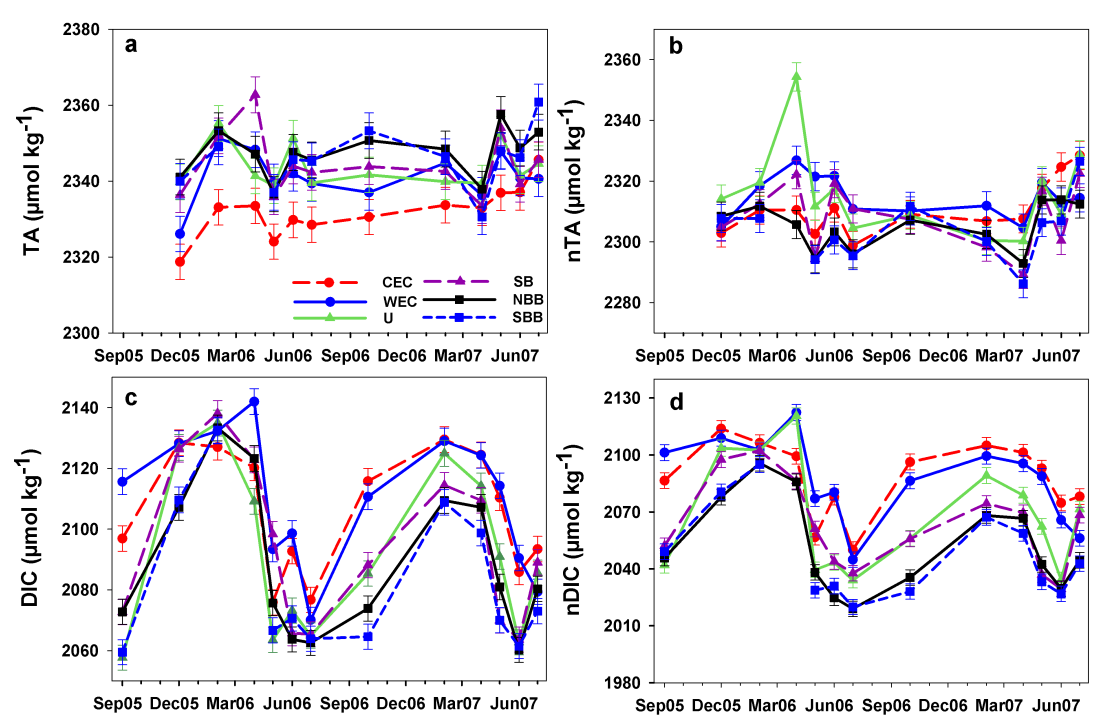

Fig. 4. Monthly mean concentrations ( $\mu \mathrm{mol} \mathrm{kg}{ }^{-1}$ ) of (a) TA, (b) nTA, (c) DIC and (d) nDIC: Central English Channel (dashed red line; circles); Western English Channel (blue line; circles); Ushant (green line; triangles); Shelf Break (dashed purple line; triangles); Northern Bay of Biscay (black line; squares); Southern Bay of Biscay (short dashed blue line; squares). Each data point represents the average of several measurements made within one part of the transect (Fig. 1). The error bars represent the standard deviation of each mean. Data points are linearly interpolated between sampling points to allow a clear distinction of observations between regions. It should not be assumed that the interpolation provides an accurate estimate of the missing data.

\subsection{Total Alkalinity}

The TA concentrations ranged between $2319 \mu \mathrm{mol} \mathrm{kg}^{-1}$ and $2363 \mu \mathrm{mol} \mathrm{kg}^{-1}$ (Fig. 4a). The normalized TA ranged from $2286 \mu \mathrm{mol} \mathrm{kg}^{-1}$ to $2329 \mu \mathrm{mol} \mathrm{kg}^{-1}$ (Figure 4b), with the exception of the Ushant anomaly in April 2006 (nTA = $2354 \mu \mathrm{mol} \mathrm{kg}^{-1}$ ) where a salinity anomaly was observed due to the influence of riverine inputs (Fig. 2a). Corbière et al. (2007) reported similar values of nTA ranging between $2327 \mu \mathrm{mol} \mathrm{kg}{ }^{-1}$ (winter 2002) and $2289 \mu \mathrm{mol} \mathrm{kg}^{-1}$ (summer 2003) for the Northwest Atlantic subpolar gyre. A drawdown in nTA was observed in most of the regions during the crossings of May and July 2006 and corresponded with the highest cell abundances (up to $0.9 \times 10^{6}$ cells $^{-1}$ and $0.4 \times 10^{6}$ cells $^{-1}$, respectively) of Emiliana huxleyi, which was the dominant coccolithophore species observed on each crossing. All other crossings showed E. huxleyi abundances of less than $0.1 \times 10^{6}$ cells $^{-1}$, which was about an order of magnitude lower than values reported during intense coccolithophore blooms in the North Atlantic (Holligan et al., 1993; Robertson et al., 1994). The seasonal distribution of TA is controlled by production and dissolution of calcium carbonate, uptake and supply of nitrate (Brewer and Goldman 1976; Wolf-Gladrow et al., 2007), and freshwater inputs or removal such as mixing, precipitation, evaporation or river inputs (Tseng et al., 2007; Bates et al., 1996b). However, due to the low coccolithophore abundances observed in this study, it is expected that the production and dissolution of calcium carbonate was not the principal factor controlling the seasonal distribution of TA.
The nTA distribution showed little variability, with the exception of the April 2006 data in the Ushant region, which indicated limitation of the normalization procedure when dealing with riverine inputs into coastal waters. The Lee et al. (2006) algorithm for the North Atlantic Ocean was used to calculate TA from sea surface salinity and sea surface temperature (SST) data during the winter months. The measured TA showed good consistency with the calculated data, with a mean difference of $5.9 \pm 4.3 \mu \mathrm{mol} \mathrm{kg}^{-1}(n=128)$, in agreement with the uncertainty reported by Lee et al. (2006).

\subsection{Dissolved Inorganic Carbon}

The DIC concentrations showed an overall increase with latitude for all crossings (Fig. 4c), ranging from $2058 \mu \mathrm{mol} \mathrm{kg}^{-1}$ (September 2005, Ushant and Southern Bay of Biscay) to $2142 \mu \mathrm{mol} \mathrm{kg}{ }^{-1}$ (April 2006, Western English Channel). The salinity-normalized DIC (nDIC) concentrations (Figure 4d) ranged from $2020 \mu \mathrm{mol} \mathrm{kg}^{-1}$ (July 2006, Southern Bay of Biscay) to $2122 \mu \mathrm{mol} \mathrm{kg}^{-1}$ (April 2006, Western English Channel). Our DIC observations were in agreement with values previously reported for the North Atlantic by Corbière et al. (2007) and Robertson et al. (1994), where DIC values ranged from $2070 \mu \mathrm{mol} \mathrm{kg} \mathrm{g}^{-1}$ in summer to $2140 \mu \mathrm{mol} \mathrm{kg}^{-1}$ in winter. This also agrees with the range reported for the Norwegian Sea, with DIC values ranging between $2140 \mu \mathrm{mol} \mathrm{kg} \mathrm{kg}^{-1}$ in winter and $2050 \mu \mathrm{mol} \mathrm{kg}{ }^{-1}$ to $2080 \mu \mathrm{mol} \mathrm{kg}{ }^{-1}$ in summer (Findlay et al., 2008). The spring chlorophyll $a$-fluorescence maxima corresponded with periods of DIC drawdown (Figs. 2e and 4c). The DIC values 
Table 2. Observed (differences based on the nitrate and DIC winter maximum and spring minimum) and estimated (from the DIC:NO3molar ratio) seasonal amplitude of DIC for the periods September 2005 to July 2006 and October 2006 to July 2007 (CEC = Central English Channel; WEC = Western English Channel; NBB = Northern Bay of Biscay; SBB = Southern Bay of Biscay).

\begin{tabular}{|c|c|c|c|c|c|c|}
\hline Year & Region & $\begin{array}{l}\Delta \text { Nitrate } \\
\text { observed }\end{array}$ & $\begin{array}{c}\triangle \mathrm{DIC} \\
\text { observed }\end{array}$ & $\begin{array}{c}\Delta \text { DIC from } \\
\text { Redfield } \\
6.6 \text { ratio }\end{array}$ & $\begin{array}{c}\Delta \mathrm{DIC} \\
\text { from } 8.0 \\
\text { ratio }\end{array}$ & $\begin{array}{l}\text { Observed } \\
\text { DIC:NO3- } \\
\quad \text { ratio }\end{array}$ \\
\hline \multirow{6}{*}{$2005 / 2006$} & CEC & 7.3 & 50 & 48 & 58 & 6.8 \\
\hline & WEC & 7.2 & 58 & 47 & 57 & 8.1 \\
\hline & Ushant & 6.2 & 63 & 41 & 49 & 10.2 \\
\hline & Shelf Break & 8.3 & 61 & 55 & 67 & 7.3 \\
\hline & NBB & 8.0 & 71 & 53 & 64 & 8.9 \\
\hline & SBB & 7.2 & 68 & 47 & 57 & 9.4 \\
\hline \multicolumn{2}{|c|}{ Average 2005/2006 } & 7.4 & 62 & 49 & 59 & 8.4 \\
\hline \multirow{6}{*}{$2006 / 2007$} & CEC & 5.2 & 36 & 34 & 41 & 7.0 \\
\hline & WEC & 5.3 & 45 & 35 & 42 & 8.5 \\
\hline & Ushant & 5.4 & 39 & 36 & 43 & 7.3 \\
\hline & Shelf Break & 4.5 & 25 & 30 & 36 & 5.7 \\
\hline & NBB & 3.9 & 29 & 26 & 31 & 7.5 \\
\hline & SBB & 4.0 & 36 & 26 & 32 & 9.0 \\
\hline \multicolumn{2}{|c|}{ Average 2006/2007 } & 4.7 & 35 & 31 & 38 & 7.5 \\
\hline
\end{tabular}

increased during the winter months corresponding to the decrease in the SST (Fig. 2b) and the minimum in $\mathrm{O}_{2}$ anomaly (Fig. 2d). During the winter of 2006/2007, however, the nitrate concentrations and the $\mathrm{O}_{2}$ anomaly suggested that the winter mixing was shallower than during the 2005/2006 winter for all regions except the Central and Western English Channel (Fig. 2c and d), leading to a smaller increase in the DIC concentration during the winter of 2006/2007 for the same regions.

\subsection{Seasonal variability of DIC and nitrate}

Surface DIC and nitrate concentrations were higher in winter than in summer as a result of carbon and nutrient enriched deep waters being brought to the surface due to deep winter mixing (Tseng et al., 2007; Bates et al., 1996b). The increase in phytoplankton biomass observed during spring and early summer (as indicated by the chlorophyll $a$-fluorescence data in Figure 2e) resulted in a decrease in DIC concentrations (Fig. 4c), with a DIC minimum of $2063 \mu \mathrm{mol} \mathrm{kg} \mathrm{k}^{-1}$ observed in the Bay of Biscay in July 2006 and June 2007. The average seasonal amplitude for DIC and nitrate concentrations, respectively, from winter to spring was $62 \mu \mathrm{mol} \mathrm{kg}{ }^{-1}$ and $7.4 \mu \mathrm{mol}^{-1}$ in 2005/2006, and $35 \mu \mathrm{mol} \mathrm{kg}{ }^{-1}$ and $4.7 \mu \mathrm{mol} \mathrm{l}^{-1}$ in 2006/2007. From late summer to early winter, an increase in surface water DIC was observed, resulting from the enhanced oceanic $\mathrm{CO}_{2}$ uptake from the atmosphere due to increasing $\mathrm{CO}_{2}$ solubility in seawater with decreasing air and sea surface temperature (Zeebe and Wolf-Gladrow, 2001). Entrainment by autumn storms of deep waters with higher DIC content also increased surface water DIC concentrations.

We used a DIC: $\mathrm{NO}_{3}^{-}$molar ratio (calculated from the seasonal depletion of DIC and nitrate) to estimate the seasonal DIC amplitude expected due to nitrate drawdown (Table 2). This ratio ranged from 5.7 to 10.3 (Table 2), indicating strong carbon over-consumption in this region compared to nitrate consumption. An averaged ratio of 8.0 was shown to give a better estimate of the seasonal carbon consumption between winter and summer than the Redfield ratio of 6.6. This disagreement with the standard Redfield $\mathrm{C}: \mathrm{N}$ ratio is often observed in coastal waters due to a more efficient recycling of nitrogen compared to carbon (Sambrotto et al., 1993). A similar discrepancy was observed in separate studies of the Northeast Atlantic (Körtzinger et al., 2001) and the Norwegian Sea (Findlay et al., 2008), where the use of data on nitrate consumption and a Redfield $\mathrm{C}: \mathrm{N}$ ratio (6.6) was also shown to significantly underestimate the carbon consumption.

\subsection{Influence of winter mixing on the carbonate system variability}

The cold winter of 2004/2005 in the Bay of Biscay with dry and cold north and northeasterly winds had a strong effect on the surface layer characteristics due to a decrease in SST and enhanced winter mixing (Somavilla et al., 2009). The heat losses from the ocean to the atmosphere for this winter in the Bay of Biscay resulted in the highest accumulated density flux on record since the 1960s (Somavilla 

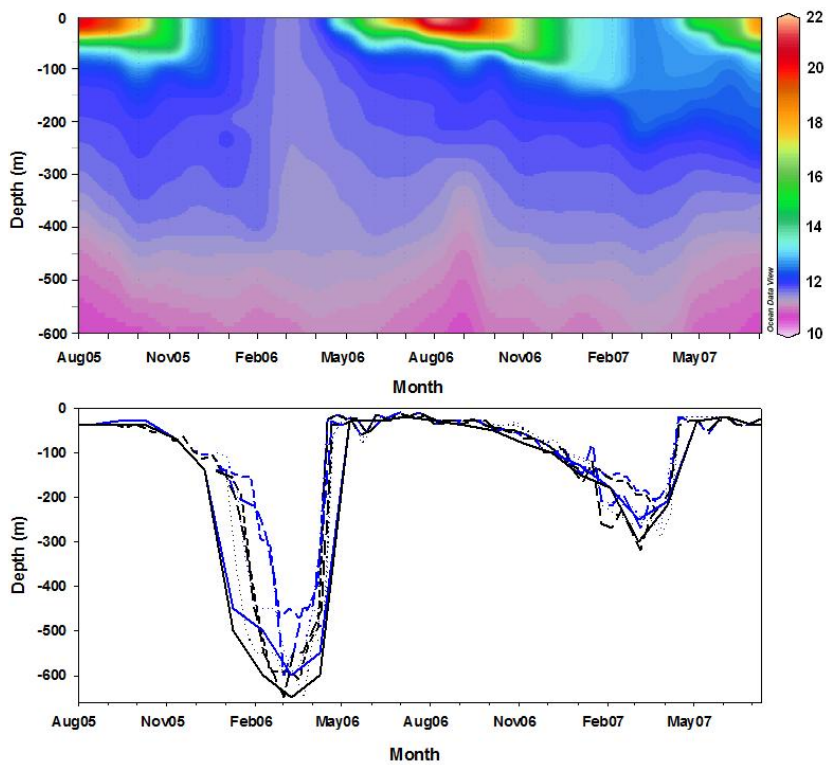

Fig. 5. Argo float 6900362 temperature data for the Bay of Biscay for the period between August 2005 and July 2007 in the upper $600 \mathrm{~m}$ (top panel), and mixed layer depths (MLD) calculated from the Argo floats 4900557 (short dashed line), 6900359 (dotted line), 6900360 (long dashed line) and 6900362 (solid line) data (bottom panel) with $\Delta \mathrm{T}$ (depth-surface) of $-0.5^{\circ} \mathrm{C}$ (blue line) and $\Delta \sigma_{t}$ (depth-surface) of 0.125 (black line) for the period between August 2005 and July 2007 (http://www.coriolis.eu.org/cdc/argo.htm).

et al., 2009). The SST anomaly extended into the following winter (2005/2006), resulting in a second winter of deep winter mixing. The air temperature during the subsequent winter of 2006/2007 was estimated to be the warmest on record for about 500 years (Luterbacher et al., 2007), causing warming of the surface ocean and a reduction in winter mixing. The winter MLD in the Bay of Biscay was estimated from the Argo floats temperature data to be between 450 and $650 \mathrm{~m}$ in 2005/2006, and between 200 and $300 \mathrm{~m}$ in 2006/2007 (Fig. 5). The MLD observed for 2006/2007 corresponded to the average MLD observed between 2002 and 2004 (approximately $200 \mathrm{~m}$ ) for the Bay of Biscay (Padin et al., 2008). The deeper MLD during the 2005/2006 winter resulted in higher surface winter concentrations of nutrients and DIC, and an enhancement of the spring bloom in the Bay of Biscay in 2006 (Figs. 2e and 3). The intensity of the spring bloom was reduced in 2007 as a result of a reduced winter mixing in 2006/2007. The inter-annual differences in DIC and nitrate concentrations were similarly affected by the difference in winter mixing in the Bay of Biscay, with winter nitrate concentrations 1.6 times higher in 2005/2006 compared with 2006/2007. This agreed with the differences in phytoplankton biomass, derived from the chlorophyll $a$ fluorescence data, observed between the two years (ratio of 1.7 between the two years).
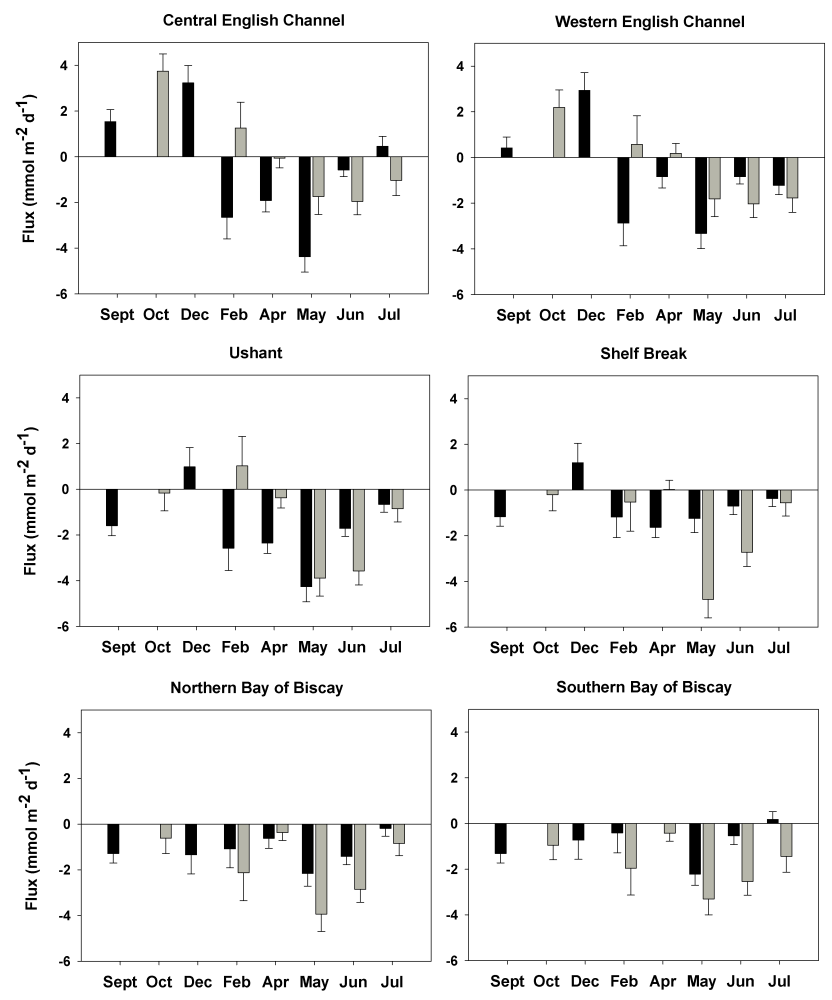

Fig. 6. Calculated monthly air-sea $\mathrm{CO}_{2}$ fluxes $\left(\mathrm{mmol} \mathrm{m}^{-2} \mathrm{~d}^{-1}\right.$; negative values indicate a net flux into the sea) for each region in 2005/2006 (dark grey) and 2006/2007 (light grey).

Inter-annual and seasonal variations in DIC concentrations in the North Atlantic Ocean have been reported to be dependent on the winter MLD and SST anomalies (Gruber et al., 2002; Bates 2001). The NAO has been shown to relate to changes in the MLD associated with anomalies in SST and convection (Dickson et al., 1996; Gruber et al., 2002). In this region, a more negative phase of the NAO is associated with stronger winter mixing, negative SST anomalies, higher winter DIC concentrations (due to the deep supply from vertical mixing) and lower spring/summer DIC concentrations (due to increased primary production); whereas a more positive NAO phase is accompanied by warmer SSTs, less intense winter mixing, and a less pronounced seasonal cycle of DIC (Gruber et al., 2002).

\subsection{Air-Sea $\mathrm{CO}_{2}$ fluxes}

The calculated air-sea $\mathrm{CO}_{2}$ fluxes $\left(\mathrm{F}_{\mathrm{CO}_{2}}\right)$ showed significant differences between the various regions (Fig. 6). The English Channel acted as a seasonal source of $\mathrm{CO}_{2}$ to the atmosphere during autumn and winter months and as a sink during spring and summer months (from $+3.7 \mathrm{mmol} \mathrm{m}^{-2} \mathrm{~d}^{-1}$ in winter, to $-4.4 \mathrm{mmol} \mathrm{m}^{-2} \mathrm{~d}^{-1}$ in summer). This is in agreement with other studies in this area (Frankignoulle et al., 1996a; Borges and Frankignoulle 2003; Padin et al., 


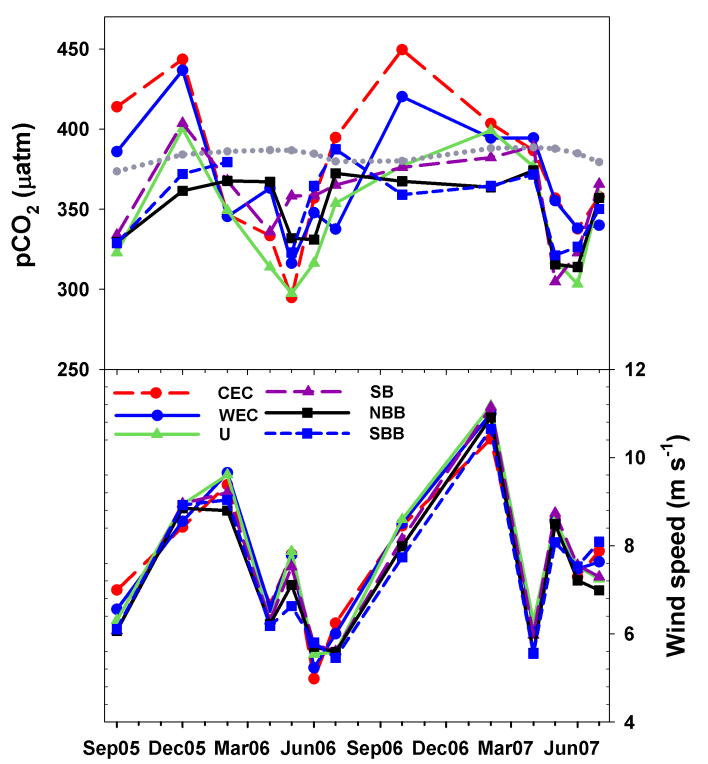

Fig. 7. Monthly mean calculated sea surface $p \mathrm{CO}_{2}$ ( $\left.\mu \mathrm{atm}\right)$ for each region (upper plot with left axis), atmospheric $p \mathrm{CO}_{2}$ data ( $\mu \mathrm{atm}$; dotted grey line in upper plot with left axis), and QuikSCAT wind speed data $\left(\mathrm{m} \mathrm{s}^{-1}\right.$; lower plot with right axis). Central English Channel (dashed red line; circles); Western English Channel (blue line; circles); Ushant (green line; triangles); Shelf Break (dashed purple line; triangles); Northern Bay of Biscay (black line; squares); Southern Bay of Biscay (short dashed blue line; squares). Data points are linearly interpolated between sampling points to allow a clear distinction of observations between regions. It should not be assumed that the interpolation provides an accurate estimate of the missing data.

2007). Heterotrophic processes involving degradation of the enhanced organic matter levels in the well-mixed waters of the English Channel explain the oversaturation of $\mathrm{CO}_{2}$ with the consequent $\mathrm{CO}_{2}$ flux out of the water column during autumn and winter (Borges and Frankignoulle 2003; Borges et al., 2006). In contrast, the Bay of Biscay acted as a sink of $\mathrm{CO}_{2}$ during all seasons, with the exception of July 2006 for the Southern Bay of Biscay. Fluxes ranged between +0.2 and $-3.9 \mathrm{mmol} \mathrm{m}^{-2} \mathrm{~d}^{-1}$, consistent with the results of Padin et al. (2008 and 2009) and Frankignoulle and Borges (2001).

Despite a few gaps in the monthly data available for the flux estimates, a good coverage of the seasonal cycle was available for the two years. The air-sea fluxes showed clear differences between similar months in 2005/2006 compared with 2006/2007, apart from the Central English Channel, the Western English Channel and the Ushant regions. The latter regions did not show a significant difference between the two years (paired t-test, $p=0.14, n=18$ ). In all other regions, May, June and July 2007 showed an increase in the oceanic $\mathrm{CO}_{2}$ sink, with the air-sea fluxes between 1.3 and 7.9 times larger compared with May, June and July 2006 (paired t-test, $p=0.0004, n=11 ; p=0.009$ for all months, $n=17$ ).
The wind speeds (Fig. 7) were higher in February, May, June and July 2007 compared to 2006, which may have influenced the air-sea $\mathrm{CO}_{2}$ flux differences observed in the Bay of Biscay and the Shelf break regions between the two years. The winter $2005 / 2006$ was colder than winter $2006 / 2007$ by $2.6^{\circ} \mathrm{C}$, while the summer of 2005/2006 was warmer than the summer of $2006 / 2007$ by $2{ }^{\circ} \mathrm{C}$ (Fig. 2b). This resulted in winter to summer SST differences of about $7.8^{\circ} \mathrm{C}$ in $2005 / 2006$ and $3.4^{\circ} \mathrm{C}$ in $2006 / 2007$, leading to enhanced solubility of $\mathrm{CO}_{2}$ in the summer of 2007 compared to 2006.

After the colder winter (2005/2006), the following seasonal changes occurred upon transition to summer (with their estimated impacts on the air-sea $\mathrm{CO}_{2}$ flux, in $\mathrm{mmol} \mathrm{m}^{-2} \mathrm{~d}^{-1}$, given in brackets, see Table 3 for method of calculation): wind speed decreased by $4 \mathrm{~m} \mathrm{~s}^{-1}(+0.9)$; temperature increased by $7.8^{\circ} \mathrm{C}(+5.7)$; and DIC decreased by $67 \mu \mathrm{mol} \mathrm{kg}{ }^{-1}$ (-6.2). After the warmer winter of 2006/2007 however, the following seasonal changes occurred: wind speed decreased by $3 \mathrm{~m} \mathrm{~s}^{-1}(+0.8)$; temperature increased by $3.4^{\circ} \mathrm{C}(+2.5)$; and DIC decreased by $49 \mu \mathrm{mol} \mathrm{kg}^{-1}(-4.2)$. The seasonal changes in DIC and SST both had important impacts on air-sea flux of $\mathrm{CO}_{2}$ (Table 3). In terms of differences between years, it appears that the effects on airsea $\mathrm{CO}_{2}$ flux of the greater seasonal warming following the colder winter $(+3.2)$ and lower wind speed $(+0.1)$ outweighed the effect of stronger spring blooms in $2006(-2.0)$. According to our analysis, the effect of the difference in winter mixing between the two years was therefore counteracted and in fact overwhelmed by the greater amount of warming of the surface waters. It was this latter factor, we calculate, which led to a stronger $\mathrm{CO}_{2}$ sink in summer 2007 compared to summer 2006. Our observations for the Bay of Biscay are consequently in contrast to recent model results for the stratified northern North Sea, where biological production, and not temperature, was emphasized as the main driver for the air-sea flux of $\mathrm{CO}_{2}$ (Prowe et al., 2009).

\section{Conclusions}

The changes in winter mixing and SST observed between the two consecutive years of our study period showed loweramplitude seasonal cycles of nitrate and DIC and an associated decrease in primary production following the warmer winter of 2006/2007. While no particular changes were observed in the English Channel regions, elsewhere an enhanced carbon uptake from the atmosphere to the ocean was observed in the summer of 2007 compared to the summer of 2006. This occurred despite more intense phytoplankton blooms in spring 2006 compared with 2007. We attribute the surprisingly lower ocean carbon uptake in summer 2006 to a greater amount of warming from winter to summer (SST increase of $8{ }^{\circ} \mathrm{C}$ between February and July in 2006, compared with only $3.4^{\circ} \mathrm{C}$ in 2007). This greater degree of warming tended to increase surface ocean $p \mathrm{CO}_{2}$ towards higher 
Table 3. Effect of varying wind speed $\left(\mathrm{m} \mathrm{s}^{-1}\right)$, temperature $\left({ }^{\circ} \mathrm{C}\right)$ and DIC concentration $\left(\mu \mathrm{mol} \mathrm{kg}{ }^{-1}\right)$ on the air-sea $\mathrm{CO}_{2}$ flux calculation in mmol m${ }^{-2} \mathrm{~d}^{-1}$. Fluxes were calculated according to Eq. 3. The oceanic $p \mathrm{CO}_{2}$ values were calculated from DIC, TA, salinity, and temperature data using the $\mathrm{CO}_{2} \mathrm{SYS}$ program. The calculation considered only one varying parameter at a time while all other parameters were considered constant: $\mathrm{TA}=2350 \mu \mathrm{mol} \mathrm{kg}{ }^{-1} ; S=35 ; T=16$; wind speed $=8 \mathrm{~m} \mathrm{~s}^{-1}$; DIC $=2100 \mu \mathrm{mol} \mathrm{kg}^{-1}$; and atmospheric $p \mathrm{CO}_{2}=$ $380 \mu \mathrm{atm}$.

\begin{tabular}{llcccc}
\hline Varying parameter & Season & Value & $\begin{array}{c}\text { Flux } \\
\text { calculated }\end{array}$ & $\begin{array}{c}\text { Seasonal } \\
\text { difference }\end{array}$ & $\begin{array}{c}\text { Flux } \\
\text { difference }\end{array}$ \\
\hline \multirow{2}{*}{ Wind speed $\left(\mathrm{m} \mathrm{s}^{-1}\right)$} & Winter 2005/2006 & 10 & -1.5 & & \\
& Summer 2006 & 6 & -0.6 & 4 & +0.9 \\
& Winter 2006/2007 & 11 & -1.8 & & \\
& Summer 2007 & 8 & -1.0 & 3 & +0.8 \\
& Winter 2005/2006 & 10.8 & -4.2 & & \\
Temperature $\left({ }^{\circ} \mathrm{C}\right)$ & Summer 2006 & 18.6 & +1.5 & 7.8 & +5.7 \\
& Winter 2006/2007 & 13.4 & -2.4 & & \\
& Summer 2007 & 16.8 & +0.1 & 3.4 & +2.5 \\
& Winter 2005/2006 & 2131 & +2.7 & & \\
DIC $\left(\mu \mathrm{mol} \mathrm{kg}{ }^{-1}\right)$ & Summer 2006 & 2064 & -3.5 & 67 & -6.2 \\
& Winter 2006/2007 & 2111 & +0.5 & & \\
& Summer 2007 & 2062 & -3.7 & 49 & -4.2 \\
\hline
\end{tabular}

values in summer 2006, and was sufficiently strong to offset the effects of the stronger phytoplankton blooms in that year. Stronger winds in summer 2007 compared with summer 2006 also contributed to an increased carbon uptake in summer 2007. While upper ocean stratification is expected to increase due to further $\mathrm{CO}_{2}$ emissions, with the prediction that this will lead to decreased oceanic $\mathrm{CO}_{2}$ uptake, we show in this study that a decrease in winter mixing can be followed by an increase in oceanic $\mathrm{CO}_{2}$ uptake during the following summer. Our study highlights the importance of winter to summer temperature differences in controlling the annual $\mathrm{CO}_{2}$ sink in temperate waters. These results are therefore important in order to understand how the oceans might respond to future climate change and accompanying changes in stratification and storm frequency in this oceanic region.

Acknowledgements. We thank P\&O Ferries Ltd., UK, and Seatrade Reefer Chartering, Belgium, for providing access to their ships. We thank the captains, officers, and crew of P\&O Pride of Bilbao and MV Santa Maria for their assistance on all the crossings. Additional thanks go to the FerryBox team for the help provided in the maintenance of the FerryBox system and on the calibration crossings, more particularly Sue Hartman, Jon Campbell, Navjit Sagoo, Holly Niner, and Angus Roberts for their help with data collection and analysis, as well as Craig Wallace, Elizabeth Kent and Werenfrid Wimmer for their help and comments. We are also very grateful to Alberto Borges and three anonymous reviewers. This study was financially supported by a NOCS PhD studentship funding to CD, NOCS and Oceans $2025 \mathrm{PhD}$ studentship funding to AC, the NERC UK SOLAS grant (NE/C001931/1) and the European funded integrated projects CARBOOCEAN (grant number EVK2-CT-2000-00088) and EPOCA. This work is a contribution to the "European Project on Ocean Acidification"
(EPOCA) which received funding from the European Community's Seventh Framework Programme (FP7/2007-2013) under grant agreement $n^{\circ} 211384$.

Edited by: A. V. Borges

\section{References}

Bargeron, C. P., Hydes, D. J., Woolf, D. K., Kelly-Gerreyn, B. A. and Qurban, M. A.: A regional analysis of new production on the northwest European shelf using oxygen fluxes and a ship-ofopportunity, Estuar. Coast. Shelf S., 69, 478-490, 2006.

Bates, N. R.: Interannual variability of the oceanic $\mathrm{CO}_{2}$ sink in the subtropical gyre of the North Atlantic Ocean over the last 2 decades, J. Geophys. Res., 112, C09013, doi:10.1029/2006JC003759, 2007.

Bates, N. R.: Interannual variability of oceanic $\mathrm{CO}_{2}$ and biogeochemical properties in the Western North Atlantic subtropical gyre, Deep-Sea Res. Pt. II, 48, 1507-1528, 2001.

Bates, N. R., Michaels, A. F. and Knap, A. H.: Seasonal and interannual variability of oceanic carbon dioxide species at the US JGOFS Bermuda Atlantic time-series study (BATS) site, DeepSea Res. Pt. II, 43, 347-383, 1996a.

Bates, N. R., Michaels, A. F. and Knap, A. H.: Alkalinity changes in the Sargasso Sea: geochemical evidence of calcification?, Mar. Chem., 51, 347-358 1996b.

Bopp, L., Monfray, P., Aumont, O., Dufresne, J.-L., Le Treut, H., Madec, G., Terray, L. and Orr, J. C.: Potential impact of climate change on marine export production, Global Biogeochem. Cy., 15, 81-99, 2001.

Borges, A. V. and Frankignoulle, M.: Distribution of surface carbon dioxide and air-sea exchange in the English Chan- 
nel and adjacent areas, J. Geophys. Res., 108, C53140, doi:10.1029/2000JC000571, 2003.

Borges, A. V., Schiettecatte, L.-S., Abril, G., Delille, B., and Gazeau, F.: Carbon dioxide in European coastal waters, Estuar. Coast. Shelf S., 70, 375-387, 2006.

Brewer, P. G. and Goldman, J. C.: Alkalinity changes generated by phytoplankton growth, Limnol. Oceanogr., 21, 108-117, 1976.

Caldeira, K. and Wickett, M. E.: Anthropogenic carbon and ocean pH, Nature, 425, 365, 2003.

Corbière, A., Metzl, N., Reverdin, G., Brunet, C. and Takahashi, T.: Interannual and decadal variability of the oceanic carbon sink in the North Atlantic subpolar gyre, Tellus B, 59, 168-178, 2007.

Dickson, A. G., Sabine, C. L. and Christian, J. R.: Guide to best practices for ocean $\mathrm{CO}_{2}$ measurements, PICES Special Publication 3, IOCCP report No. 8, 191 pp., 2007.

Dickson, A. G. and Millero, F. J.: A comparison of the equilibrium constants for the dissociation of carbonic acid in seawater media, Deep-Sea Res., 34, 1733-1743, 1987.

Dickson, R., Lazier, J., Meincke, J., Rhines, P. and Swift, J.: Longterm coordinated changes in the convective activity of the North Atlantic, Prog. Oceanog., 38, 241-295, 1996.

Doney, S. C., Tilbrook, B., Roy, S., Metzl, N., Le Quéré, C., Hood, M., Feely, R. A., and Bakker, D.: Surface-ocean $\mathrm{CO}_{2}$ variability and vulnerability, Deep-Sea Res. Pt. II, 56, 504-511, 2009.

Dore, J. E., Lukas, R., Sadler, D. W., Church, M. J., and Karl, D. M.: Physical and biogeochemical modulation of ocean acidification in the central North Pacific, Proc. Natl Acad. Sci., 106, 1223512240, 2009.

Fabry, V. J.: Marine calcifiers in a high- $\mathrm{CO}_{2}$ ocean, Science, 320, 1020-1022, 2008.

Feely, R. A., Sabine, C. L., Lee, K., Berelson, W., Kleypas, J., Fabry, V. J., and Millero, F. J.: Impact of anthropogenic $\mathrm{CO}_{2}$ on the $\mathrm{CaCO}_{3}$ system in the oceans, Science, 305, 362-366, 2004.

Findlay, H. S., Tyrrell, T., Bellerby, R. G. J., Merico, A., and Skjelvan, I.: Carbon and nutrient mixed layer dynamics in the Norwegian Sea, Biogeosciences, 5, 1395-1410, doi:10.5194/bg-51395-2008, 2008.

Frankignoulle, M. and Borges, A. V.: European continental shelf as a significant sink for atmospheric carbon dioxide, Global Biogeochem. Сy., 15, 569-576, 2001.

Frankignoulle, M., Bourge, I., Canon, C., and Dauby, P.: Distribution of surface seawater partial $\mathrm{CO}_{2}$ pressure in the English Channel and in the Southern Bight of the North Sea, Cont. Shelf Res., 16, 381-395, 1996a.

Frankignoulle, M., Elskens, M., Biondo, R., Bourge, I., Canon, Ch., Desgain, S., and Dauby, P.: Distribution of inorganic carbon and related parameters in surface seawater of the English Channel during spring 1994, J. Marine Syst., 7, 427-434, 1996 b.

González-Dávila, M. and Santana-Casiano, J. M.: Seasonal and interannual variability of sea-surface carbon dioxide species at the European Station for Time Series in the Ocean at the Canary Islands (ESTOC) between 1996 and 2000, Global Biogeochem. Cy., 17, 1076, doi:10.1029/2002GB001993, 2003.

Grasshoff, K.: Determination of nutrients, in: Methods of Seawater Analysis, second edition, edited by: Grasshoff, K., Ehrhardt, M., and Kremling, K., Verlag Chemie GmbH, Basel, pp. 125-188, 419 pp., 1983.

Gruber, N., Keeling, C. D. and Bates, N. R.: Interannual variability in the North Atlantic Ocean carbon sink, Science, 298, 2374-
2378, 2002.

Holligan, P. M., Fernández, E., Aiken, J., Balch, W. M., Boyd, P., Burkill, P. H., Finch, M., Groom, S. B., Malin, G., Muller, K., Purdie, D. A., Robinson, C., Trees, C. C., Turner, S. M., and van der Wal, P.: A biogeochemical study of the coccolithophore, Emiliana huxleyi, in the North Atlantic, Global Biogeochem. Cy., 7, 879-900, 1993.

Hydes, D. J., Hartman, M. C., Kaiser, J., and Campbell, J. M.: Measurement of dissolved oxygen using optodes in a FerryBox system, Estuar. Coast. Shelf S., 83, 485-490, doi:10.1016/j.ecss.2009.04.014, 2009.

Hydes, D. J., Hartman, M. C., Bargeron, C. P., Campbell, J. M., Curé, M. S., and Woolf, D. K.: A study of gas exchange during the transition from deep winter mixing to spring bloom in the Bay of Biscay measured by continuous observation from a ship of opportunity, Journal of Operational Oceanography, 1(2), 4150,2008

Hydes, D. J., Yool, A., Campbell, J. M., Crisp, N. A., Dodgson, J., Dupee, B., Edwards, M., Hartman, S. E., Kelly-Gerreyn, B. A., Lavin, A. M., González-Pola, C. M. and Miller, P.: Use of a Ferry-Box system to look at shelf sea and ocean margin processes, edited by: Dahlin, H., Flemming, N. C., Nittis, K., Petersson, S. E., Building of the European Capacity in Operational Oceanography, Elsevier Oceanography Series, 69, $297-$ 303, 2003.

Kelly-Gerreyn, B. A., Hydes, D. J., Jégou, A. M., Lazure, P., Fernand, L. J., Puillat, I., and Garcia-Soto, C.: Low salinity intrusions in the western English Channel, Cont. Shelf Res., 26, 1241-1257, 2006.

Körtzinger, A., Koeve, W., Kähler, P., and Mintrop, L.: C:N ratios in the mixed layer during the productive season in the northeast Atlantic Ocean. Deep-Sea Res. Pt. I, 48, 661-688, 2001.

Lee, K., Tong, L. T., Millero, F. J., Sabine, C. L., Dickson, A. G., Goyet, C., Park, G.-H., Wanninkhof, R., Feely, R. A., and Key, R. M.: Global relationships of total alkalinity with salinity and temperature in surface waters of the world's oceans, Geophys. Res. Lett., 33, L19605, doi:10.1029/2006GL027207, 2006.

Luterbacher, J., Liniger, M. A., Menzel, A., Estrella, N., DellaMarta, P. M., Pfister, C., Rutishauser, T., and Xoplaki, E.: Exceptional European warmth of autumn 2006 and winter 2007: historical context, the underlying dynamics, and its phonological impacts, Geophys. Res. Lett., 34, L12704, doi:10.1029/2007GL029951, 2007.

Mehrbach, C., Culberson, C. H., Hawley, J. H., and Pytkowicz, R. M.: Measurement of the apparent dissociation constants of carbonic acid in seawater at atmospheric pressure, Limnol. Oceanogr., 18, 897-907, 1973.

Millero, F. J., Lee, K., and Roche, M.: Distribution of Alkalinity in the Surface Waters of the Major Oceans, Mar. Chem., 60, 111130, 1998a.

Millero, F. J., Dickson, A. G., Eischeid, G., Goyet, C., Guenther, P., Johnson, K. M., Key, R. M., Lee, K., Purkenson, D., Sabine, C. L., Schottle, R. G., Wallace, D. W. R., Lewis, E., and Winn, C. D.: Assessment of the quality of the shipboard measurements of total alkalinity on the WOCE Hydrographic Program Indian Ocean $\mathrm{CO}_{2}$ survey cruises 1994-1996, Mar. Chem., 63, 9-20, 1998 b.

Monterey, G. and Levitus, S.: Seasonal variability of mixed layer depth for the world ocean. NOAA Atlas, NESDIS 14, Washing- 
ton D.C., 96 pp, 1997.

Morel, A. and Prieur, L.: Analysis of variations in ocean color, Limnol. Oceanogr., 22(4), 709-722, 1977.

Nightingale, P. D., Malin, G., Law, C. S., Watson, A. J., Liss, P. S., Liddicoat, M. I., Boutin, J., and Upstill-Goddard, R. C.: In situ evaluation of air-sea gas exchange parameterizations using novel conservative and volatile tracers, Global Biogeochem. Cy., 14, 373-387, 2000.

Orr, J. C., Fabry, V. J., Aumont, O., Bopp, L., Doney, S. C., Feely, R. A., Gnanadesikan, A., Gruber, N., Ishida, A., Joos, F., Key, R. M., Lindsay, K., Maier-Reimer, E., Matear, R., Monfray, P., Mouchet, A., Najjar, R. G., Plattner, G.-K., Rodgers, K. B., Sabine, C. L., and Sarmiento, J. L.: Anthropogenic ocean acidification over the twenty-first century and its impact on calcifying organisms, Nature, 437, 681-686, 2005.

Padin, X. A., Navarro, G., Gilcoto, M., Rios, A. F., and Pérez, F. F.: Estimation of air-sea $\mathrm{CO}_{2}$ fluxes in the Bay of Biscay based on empirical relationships and remotely sensed observations, J. Marine Syst., 75, 280-289, 2009.

Padin, X. A., Castro, C. G., Ríos, A. F., and Pérez, F. F.: $f \mathrm{CO}_{2}^{S W}$ variability in the Bay of Biscay during ECO cruises, Cont. Shelf Res., 28, 904-914, 2008.

Padin, X. A., Vázquez-Rodríquez, M., Ríos, A. F., and Pérez, F. F.: Surface $\mathrm{CO}_{2}$ measurements in the English Channel and Southern Bight of North Sea using voluntary observing ships, J. Marine Syst., 66, 297-308, 2007.

Pierrot, D., Lewis, E., and Wallace, D. W. R.: MS Excel Program Developed for $\mathrm{CO}_{2}$ System Calculations., ORNL/CDIAC-105. Carbon Dioxide Information Analysis Center, Oak Ridge National Laboratory, U.S. Department of Energy, Oak Ridge, Tennessee, 2006.

Prowe, A. E. F., Thomas, H., Pätsch, J., Kühn, W., Bozec, Y., Schiettecatte, L., Borges, A. V., and de Baar, H. J. W.: Mechanisms controlling the air-sea $\mathrm{CO}_{2}$ flux in the North Sea, Cont. Shelf Res., 29, 1801-1808, 2009.

Robertson, J. E., Robinson, C., Turner, D. R., Holligan, P., Watson, A. J., Boyd, P., Fernandez, E., and Finch, M.: The impact of a coccolithophore bloom on oceanic carbon uptake in the northeast Atlantic during summer 1991, Deep-Sea Res. Pt. I, 41, 297-314, 1994.

Sabine C. L., Feely, R. A., Gruber, N., Key, R. M., Lee, K., Bullister, J. L., Wanninkhof, R., Wong, C. S., Wallace, D. W. R., Tilbrook, B., Millero, F. J., Peng, T.-H., Kozyr, A., Ono, T., and Rios, A. F.: The oceanic sink for anthropogenic $\mathrm{CO}_{2}$, Science, 305, 367-371, 2004.

Sambrotto, R.N., Savidge, G., Robinson, C., Boyd, P., Takahashi, T., Karl, D.M., Langdon, C., Chipman, D., Marra, J. and Codispoti, L. Elevated consumption of carbon relative to nitrogen in the surface ocean. Nature 363, 248-250 (1993).

Sarmiento, J. L., Hughes, T. M. C., Stouffer, R. J., and Manabe, S.: Simulated response of the ocean carbon cycle to anthropogenic climate warming, Nature, 393, 245-249, 1998.

Schuster, U., Watson, A. J., Bates, N. R., Corbière, A., GonzalezDavila, M., Metzl, N., Pierrot, D., and Santana-Casiano, M.: Trends in North Atlantic sea-surface $f \mathrm{CO}_{2}$ from 1990 to 2006, Deep-Sea Res. Pt. II, 56, 620-629, 2009.

Schuster, U. and Watson, A. J.: A variable and decreasing sink for atmospheric $\mathrm{CO}_{2}$ in the North Atlantic, J. Geophys. Res., 112, C11006, doi:10.1029/2006JC003941, 2007.
Somavilla, R., González-Pola, C., Rodriguez, C., Josey, S. A., and Sánchez, R. F.: Large changes in the hydrographic structure of the Bay of Biscay after the extreme mixing of winter 2005, J. Geophys. Res., 114, C01001, doi:10.1029/2008JC004974, 2009.

Sweeney, C., Gloor, E., Jacobson, A. R., Key, R. M., McKinley, G., Sarmiento, J. L., and Wanninkhof, R.: Constraining global air-sea gas exchange for $\mathrm{CO}_{2}$ with recent bomb $\mathrm{CO}_{2}$ measurements, Global Biogeochem. Cy., 21, GB2015, doi:10.1029/2006GB002784, 2007.

Takahashi, T., Sutherland, S. C., Wanninkhof, R., Sweeney, C., Feely, R. A., Chipman, D. W., Hales, B., Friederich, G., Chavez, F., Sabine, C., Watson, A., Bakker, D. C. E., Schuster, U., Metzl, N., Yoshikawa-Inoue, H., Ishii, M., Midorikawa, T., Nojiri, Y., Körtzinger, A., Steinhoff, T., Hoppema, M., Olafsson, J., Arnarson, T. S., Tilbrook, B., Johannessen, T., Olsen, A., Bellerby, R., Wong, C. S., Delille, B., Bates, N. R., and de Baar, H. J. W.: Climatological mean and decadal change in surface ocean $p \mathrm{CO}_{2}$, and net sea-air $\mathrm{CO}_{2}$ flux over the global oceans, Deep-Sea Res. Pt. II, 56, 554-577, 2009.

Takahashi, T., Sutherland, S. C., Sweeney, C., Poisson, A., Metzl, N., Tilbrook, B., Bates, N., Wanninkhof, R., Feely, R. A., Sabine, C., Olafsson, J., and Nojiri, Y.: Global sea-air $\mathrm{CO}_{2}$ flux based on climatological surface ocean $p \mathrm{CO}_{2}$ and seasonal biological and temperature effects, Deep-Sea Res. Pt. II, 49, 1601-1622, 2002.

Thomas, H., Prowe, A. E. F., Lima, I. D., Doney, S. C., Wanninkhof, R., Greatbatch, R. J., Schuster, U., and Corbière, A.: Changes in the North Atlantic Oscillation influence $\mathrm{CO}_{2}$ uptake in the North Atlantic over the past 2 decades, Global Biogeochem. Cy., 22, GB4027, doi:10.1020/2007GB003167, 2008.

Tseng, C.-M., Wong, G. T. F., Chou, W.-C., Lee, B.-S., Sheu, D.D., and Liu, K.-K.: Temporal variations in the carbonate system in the upper layer at the SEATS station, Deep-Sea Res. Pt. II, 54, 1448-1468, 2007.

Tyrrell, T., Schneider, B., Charalampopoulou, A., and Riebesell, U.: Coccolithophores and calcite saturation state in the Baltic and Black Seas, Biogeosciences, 5, 485-494, doi:10.5194/bg-5485-2008, 2008.

Vantrepotte, V., Brunet, C., Mériaux, X., Lécuyer, E., Velluci, V., and Santer, R.: Bio-optical properties of coastal waters in the Eastern English Channel, Estuar. Coast. Shelf S., 72, 201-212, 2007.

Wanninkhof, R., Lewis, E., Feely, R. A., and Millero, F. J.: The optimal carbonate dissociation constants for determining surface water $p \mathrm{CO}_{2}$ from alkalinity and total inorganic carbon, Mar. Chem., 65, 291-301, 1999.

Wanninkhof, R.: Relationship between wind speed and gas exchange over the ocean, J. Geophys. Res., 97, 7373-7382, 1992.

Weiss, R. F.: Carbon dioxide in water and seawater: the solubility of a non-ideal gas, Mar. Chem., 2, 203-215, 1974.

Wolf-Gladrow, D. A., Zeebe, R. E., Klaas, C., Körtzinger, A., and Dickson, A. G.: Total Alkalinity: the explicit conservative expression and its application to biogeochemical processes, Mar. Chem., 106, 287-300, 2007.

Wollast, R. and Chou, L.: The carbon cycle at the ocean margin in the northern Gulf of Biscay, Deep-Sea Res. Pt. II, 48, 3265-3293, 2001.

Zeebe R. E. and Wolf-Gladrow, D. A.: $\mathrm{CO}_{2}$ in seawater: equilibrium, kinetics, isotopes, Elsevier Oceanography Series 65, Amsterdam, 346 pp, 2001. 